$5.22,23$ ； $\rightarrow$ 本誌 (昭29) 614, (昭30) 385, (昭31)57)。 石炭化学に 5 千万円など（工技院研究輩配分）避 省注 7 日, 同院さん下試験, 研究所门 31 年度研聟費 （億四） 6.46 (指定=石炭化学 0.50 , 原子炉用炭素材 0.15 (名号，329), 核原料物咓調查 1, 放射線標準》 磪立 0.25 なぞ 2.79 , 特別=電氻技術なぞ 46 項目 3.67) せを(日経, 5.8 ; 日刊工, $5.11,16$ 化学と 工業 9 (6) 279)

低いおう重油確保人鉄鋼むけ上期低い招ら重油（万 k1）の不足々 12 （消費 $44^{*}$, 国産 12 , 輸入 20）のみこ みで, 政府汶, 重油分の多いワフラ，サンノーキン原 油などの輸入をすすめるとともに，三菱，昭和，出光 尔ぞの脫硫装置輸入に企業合理化法艺適用して免稅， また資技試の重油脫硫研究に 31 年度 340 万田を支出す る。(日経，5.12）*本誌， 3 月， 173

岩国旧陸然払下 (三井石㴼化学)1）（カッコ內価格, 億四）土地 9.5 万仹 (1.56), 建物6700坡 (1.12), 機 械1950台（器具々も2.08）などの払下について23日， 中国財務局との間で調印した。来年11月から操業には いる。(同5.24)

滍界寸信 日本石油化学 ${ }^{1}$ ：23日, 川崎工場（大師河 原）起工。年末完成のみこみ。工費11億円。日石の接 触改質油 (5600bb1/日) からのプロピレン妾利用する （日経, 日刊工，(5.24)。をた日石中研の石油化学 (アセトン誘導体) 工業化プラント（５千万田）の火 入式は25日，同工場內で行われた（日刊工，5.27）。 昭石 (四日市) : 活用計画 (本誌 (昭30)608) をか

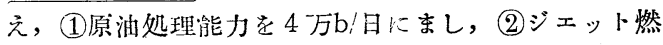
料精製装置をうける, (3)設借资金115 億内, (4)借用 地 30 万坡などを申請した（日経，5.25)。杂善（下津） : IPA 計画（本誌（昭30）386）を中止する。理由泣 (1)特許料が高い，(2)FCCガスは燃料にむけるなど（日 刊工，(5.6)。菱石：トッピング (2.5万b/日) を 6 月 着工, 工期 1 年, 工費 8 億四。脫塩, 脫硫装置付（同 5.9 )。東燃（清水）：1年末元から蒸留塔上部内代り に $\mathrm{Ti}$ 板（佳友金属）を用いているが余くふ食学》と めない(同，5.26)。な和同社纹このほど种奈川県庁 们川骖埋立予定地10万坪の払下を申入れたという（同 2.21)。

合成レジン生産目標 (35 年度)引上 涌産省纹昨年 6 月の 5 年計画次のよ5に改めた（千 t，（）內31年 度): フェノールレジン 16.5 (13.4), ニリア同65(50) 塩化ビ =ール同 72 (55), メタクリル同 3(1.2), ケイ ソ同 0.7 (0.3)，フッソ同0.6(0.2)，アルキッド同 8.5

1）本袺（昭30）311，(昭31） 171
(6.2), ポリェステル同3.5(1), ポリスチレ゙ン12(1.1) ポリエチレン 25(0), サク酸センイ素 $7(3.1)$, 合計 213.8(131.5) (日経, 5.22,29; 日刊工, 5.23)

技術提携外資棉は 1 日, アメ.シアナミドと佳友化 学のアセチレンと青酸からアクリルニトリルなど 9 件 また15日，(1)カザレ（スイス）、と新日屴の CO 転化, (2)ペトロコーク (イタリ) と同社の $\mathrm{K}_{2} \mathrm{CO}_{3}$ Kよる $\mathrm{CO}_{2}$ 吸收, (3) モンテカチこと三菱化成りフアウザ式 メタン分解, (4)ストーンウエブスタと三非石油化学の ービカフサからエチレンとプロピレン，(5)同社を住友 化学のエチレン工場設訂など 10 件を認的（日刊工， 5.2 ; 日経, 5.16)

市況 タール成品すえおき 鋼管建值（万以/t) 6 7 月, 純ベン 1 号 7.9, トルェン 1 号 8.5, $60 \%$ ベンぜ ン $7.5,3^{\circ}$ キシレン 9.2 , ソルベントナフサ 1 号 8.6 , ピッチ1.45(日刊工，5.30)。合成フエノール値下 三 井化学では 3 四 $/ \mathrm{kg}$ さげて 227 四 $/ \mathrm{kg}$ とした(同)。メ タノール值上 佳友*につづき東圧でも 2 円 $/ \mathrm{kg}$ 上げ 大口67冋，小口72四となつを（同5.7)。*生産(千t/月， 新居浜) 今の 2 学秋から 2.6 K上げる。工費 1 億円(同 5.29)。硫安またた值下か14生産者価格（回/10貫)泣 29 肥料作度 826，30同 799 のとてろ, 政府註合理化》 進行を理由に31年度 ( 8 月〜来仵 7 月) さらに引下を のぞんでいる。(朝日, 5.29 ; 次ぺージ)

原子カニユース 電気事業連合会：40年度の発電力 (万kW) 六水力 1435 , 火力776.8 に原子力 45.4 を加 元, 計2257.2(然料の不足纺石炭として 142.9 万 $\mathrm{t}$ ) と

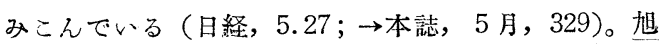
化成重水生産一：原子力委に出した計画によると，能 力 $5 \mathrm{t} /$ 年 $(99.75 \%)$ 。餈金 2.6 億四。32年着工，33年完 成（日刊工，5.11）。核融合反応の研吮一（阪大）：阔 时研究室ですでに $20000^{\circ} \mathrm{C}$ をたが，今年中に $10^{5}{ }^{\circ} \mathrm{C}$ まで元られるとら（同，5.14）。

\section{海 外 の 部}

石炭 $8 \%$ 值上（イギリス） NCB 汶 6 月 1 日から本均 $8 \%$ 上げる（元の值上汶昨年 7 月, 本誌 34 511)。

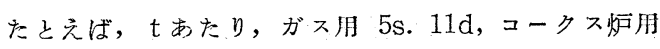
$5 \mathrm{~s} .7 \mathrm{~d}$, 鉄銅用 $6 \mathrm{~s} .8 \mathrm{~d}$, 鉄道用 $6 \mathrm{~s} .7 \mathrm{~d}$, 家庭用 $6 \mathrm{~s} . \sim$ 6s. 8d. ファナサイト纹約10s. の权上で, 鉄道でロン ドンに入る 4 級炭流 152s. 9d. となる。篔收(百万£) は '56:35, '57:61 でくりこし損 37 をかなりーら せる。Brit. Cok'g Ind. Assnでもコークス 高炉用本均 8s. 8d. イモノ用 8s. 8d.〜9s：6d。 あげ る。(タイムス, 5.29) 
アメリカの石炭事情（1955）（億 $\mathrm{t}$ ）瀝青炭生産 4.65 ('54ょり0.73まし)（ $\rightarrow$ 本誌，1月，59）。全エネルギ 供給中歴青炭の比率（\%）は 1910～20年 70,'40〜'45 年 '50，'55年 29.5。輸出(千万t) は 5('54より 1.9 ま)

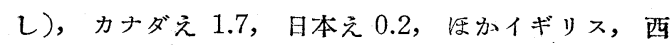
ドイッ,イタリ，オランダむけなど。探炭夫貨金は 9 月 1 日の拹定で $\$ 1.2 /$ 日の值上となつ卡。無煙炭生産 (t污) 2490 ('54:2610)。(Min. Oongr.J. 42 48, 60 ’56) (木村)

石炭から電極用カーボン（アメリカ）鉣山局のシア トル支所では，小規模テストで，A1 電解用規格にあ 5成品を光た，(Chem.Enq. News. 3 月26日，1417) レッペ法工場うごく（アメリカ） ゼネラルアニリン \&フィルムのアセチレン成品プラント, Calvert City, $\mathrm{Ky}$ は 2 月スタートした。工費 $\$ 600$ 万。（同，3月12 日, 1184)

淊界寸信 アメリカ：製油所廃がスから無水アンモニ ア10万t/年-ペトムケミカルス(レーク・チャールス, La) が City Service \& Conoco の廃がスで。工費 \$1250万，'57秋完成みこみ（闹，3月26日，1432）。1 ギリス：石油製品輸出 (1955)一(万 $\mathrm{t}$ ，（）丙億\$), 620 (2.17) 內ガソリン 125 (0.568), 潤滑油 (0.378) (同，1475)。中共：産油 (1955)一政府公表によると，
180 万 $\mathrm{t}(3.6$ 万bb1/日) で, '52 の 2.2 倍。産油能力は は’52 から 100万t/䇤ました（Oil Gas J. 1 月30 日, 137)。パキスタン:天然ガスパイプラインースイ からパンジヤブのムルタンまで 212 マイルを計画中

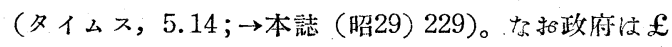
8.7 億の産業開発 5 年証画をたてている(同，5.15)。 市況 鋼材値上 アメリカ:USS，5月11日から本均 約 $1 \%$ イギリス: 同 7 日から本均 $5 \%$ ○フランス: 同 5 日から本均 $4 \%$ (日本鉄鋼輸出組合しらべ，日経 (5.20)。副生硫安*值下 アメリカ: USSは，\$10/t以 上さげて \$35（ロッキ一以東，工場わたし）とする。 *生産汶 95 万t/年。合成品核105万t/年(日経, 5.27)。 原子カニユース イギリス:コルダホールの炉は 6 月 1 日かららごく(朝日, 5.24,27)。原子力公到々 6 月 4 日の「熱核エネルギの管理」の会議に民間科学者安 招堂情報を提供する(日経，5.27)。ハーウェル研の マーレイ保健部長は 29 日, 同所設立10年記念講演で, 「このほどのアメリカ水ばくテストによる灰は20年浮 遊する」とのべた（同，5.30）。台湾： 1.15 万kW 発 電につきアメリカと恋涉中（同，5.8）。マレー：中央 電力局長ハリソン氏汶26日, 七ランゴールのコンノー トブリジ発電所 $(8$ 万W $)$ の開所式で, ’58年から原 子力がいるとのべた。(タイムス，5.28)

会 報

\section{第29回 例会講演会}

日時昭利 31 年 5 月 8 日 午後 1 時 30 分

場所日本鉱業 会館講堂

1. P. G. C. 篔熱水性ガス製造装犆

大阪无斯株式会社 清 原 省 三氏 ピーク需要に備え 1 基当りコークス $90 \mathrm{t} /$ 日, 重油 $24 \mathrm{k} 11$ を処理する 15 万 $\mathrm{m}^{3} /$ 日の装置 4 基を建設した。 この装置は低品位重油が使用可能で, レバースフロー を採用してあるので気化勃率がよい，自働操作で誤動 作に対しては緊急停止装置がすり安全確实，水洗のク リーパーバルブを犆用しバルブ故障がないなぞの特徵 を持つている。生成ガスは重油使用で，4,600 kcal $/ \mathrm{m}^{3}$ 軽油使用で $9,000 \mathrm{kcal} / \mathrm{m}^{3}$ 以上が可能でおるが現在枋 C重油を使用している。発生师迭風機は廃熱ボイラの 蒸気ターピン駆動である。

操業は 2 分本サイクルと 3 分サイクルを両方試験し
たが, 差異が認められなかつたので 3 分サイクルに決 定した。拾熱油としてB重油使用の際は $3 \%$ の゙ーン・ オフタイムで充分であつたが，C重油の際な $6 \%$ とし た。また夜間停止時な管熱器のバーン・オフと時々自 然通風するととにより発生炉本体の溫度維持をはかる。 コークス粒度 $25 \mathrm{~mm}$ 以上 $94.5 \%$ て熱收桨はコークス による熱55.89\%, 油43.72\%でガスへ移つた熟量59.86 $\%$ タールー 14.72\%, 生成ガス: $\mathrm{CO}_{2} 5.2, \mathrm{CnHm}$ 6.8, $\mathrm{O}_{2} 0.6, \mathrm{CO} 32.4, \mathrm{H}_{2} 39.8, \mathrm{CH}_{4} 8.0, \mathrm{~N}_{2} 7.2$ H. V. $4,473 \mathrm{kcal} / \mathrm{m}^{3}$ さらに成績が向上することが期 待される。

2. コッパース・トツェツク式微粉炭ガス化装置に ১いて

日本水素工業株式会社 照 辈 総 治比 原料炭としては炭価が割安で硫黃分少く，比較的炭 化度の低い常磐南部の石炭を使用している。本ガス化 